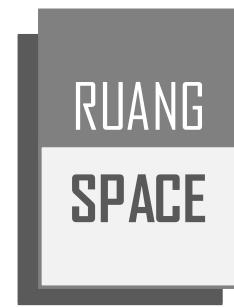

\title{
PENGARUH DESA WISATA TERHADAP PERUBAHAN PENGGUNAAN LAHAN DI DESA SEDIT KABUPATEN BANGLI
}

\author{
Oleh: Ida Rayta Wira Pratami ${ }^{1}$
}

\begin{abstract}
Government Regulation Number 16 Year 2014 of Bangli Regency in Bali stipulates that Sedit Village is among the 22 communities within this region, which are planned to be community-based tourist destinations. As is often to be the case, such a policy heavily aspires to boost the economy of all parties involved, at all different levels. This is also aim at reducing the rate of people migrating out the village and entering into the city for economic reason. However, when such a development is not well thought, it generates problems that likely cost greater than economic benefits it harvests. Contextualizing its focus on this circumstance, the article discusses impacts of the tourist industry on land development and utilization. It employs a mixed of both qualitative and quantitative research methods relying on data acquired from respondents when interviews are conducted and questionnaires are distributed. Study results corroborate the current trend of development in many developing countries in which a short-term economic gain defeats social and environmental interests, as it also takes place within the development of Sedit Village as a community-based tourism. Several relevant cases pertaining to land use changes are presented within to substantiate this assertion. Prominent among the exhibited instances is an awakening speed of paddy field conversions into numerous commercial uses to support the tourist industry. Since rice farming remains a major form of subsistence for the village, such a condition will ideally have to be taken into account, before it is too late.
\end{abstract}

Keywords: impact, community-based tourism, land use change, Sedit Village

\begin{abstract}
Abstrak
Peraturan Pemerintah No. 16 Tahun 2014 Kabupaten Bangli di Bali menetapkan Desa Sedit sebagai salah satu dari dua puluh dua Desa Wisata, yang direncanakan untuk menjadi tempat Pariwisata berbasis komunitas. Seperti sering terjadi, kebijakan tersebut ditujukan untuk meningkatkan ekonomi semua pihak yang terlibat, pada level berbeda. Ini bertujuan untuk mengurangi jumlah orang yang bermigrasi keluar Desa dan memasuki kota karena alasan ekonomi. Namun, ketika perkembangan semena-mena tidak dikelola dengan baik, akan menghasilkan masalah yang mungkin menyebabkan biaya lebih besar dari manfaat ekonomi yang didapat. Mengkontekstualisasikan fokusnya pada keadaan ini, artikel ini membahas dampak industri pariwisata terhadap pemanfaatan lahan. Penelitian ini menggunakan metode penelitian kualitatif dan kuantitatif dengan mengandalkan data yang diperoleh dari responden dengan teknik wawancara dan pendistribusian kuesioner. Hasil studi menguatkan kecenderungan perkembangan yang terjadi di banyak negara berkembang di mana keuntungan ekonomi jangka pendek mengalahkan kepentingan sosial dan lingkungan. Kondisi ini juga terjadi dalam pengembangan Desa Sedit sebagai destinasi pariwisata berbasis masyarakat. Beberapa kasus relevan yang berkaitan dengan perubahan penggunaan lahan disajikan untuk mendukung pernyataan ini. Yang menonjol di antara pernyataan yang telah dipaparkan adalah kecepatan konversi sawah menjadi fungsi komersial untuk pendukung industri pariwisata. Karena pertanian tetap menempati posisi utama sumber pengihidupan di desa, kondisi seperti itu idealnya harus diperhitungkan, sebelum terlambat.
\end{abstract}

Kata kunci: Pengaruh, Pariwisata Berbasis Komunitas, Perubahan Penggunaan Lahan, Desa Sedit

1 Program Studi Magister Arsitektur Universitas Udayana. Email: idaraytawirapratami@gmail.com 


\section{Pendahuluan}

Aktivitas pariwisata dapat memberikan dampak positif bagi perekonomian, seperti penghasilan devisa yang cukup besar, mendorong investasi infrastruktur, menstimulasi industri-industri lainnya. Dampak negatif yang terjadi di lapangan adalah untuk mencapai tujuan ekonomi ada aspek lingkungan yang harus dikorbankan. Kedua hal tersebut merupakan sesuatu yang bertentangan yang jika dibiarkan maka sulit mencapai konsep pariwisata berkelanjutan.

Pariwisata merupakan suatu kegiatan wisata sebagai kebutuhan manusia yang terwujud dalam keterkaitan kegiatan yang dilakukan wisatawan dengan fasilitas dan pelayanan dari masyarakat, pemerintah dan swasta (Warpani, 2007). Keterkaitan kegiatan ini yang menjadikan kegiatan pariwisata membutuhkan dan menempati suatu ruang wilayah dalam pengembangannya

Pada Rencana Tata Ruang Wilayah Kabupaten Bangli Tahun 2012 disebutkan, bahwa Desa Sedit merupakan salah satu kawasan strategis dengan fungsi sebagai kawasan budidaya. Fungsi pada kategori ini adalah wilayah yang ditetapkan dengan fungsi utama untuk dibudidayakan sehingga harus ada pengendalian penggunaan lahan agar fungsi utamanya tidak terganggu.

Sesuai dengan Peraturan Bupati Bangli No 16 Tahun 2014, Desa Sedit Kelurahan Bebalang Kabupaten Bangli ditetapkan sebagai Desa Wisata. Dengan dibentuk menjadi desa wisata, diharapkan dapat menggulirkan perekonomian di desa, sehingga memperkecil arus urbanisasi dan membantu mengentaskan kemiskinan. Perkembangan Pariwisata di Desa Sedit dimulai dari tahun 1991 yang ditandai dengan masuknya wisatawan mancanegara. Dalam waktu yang singkat tempat ini mampu menarik banyak wisatawan yang berkunjung. Dapat dilihat dari lonjakan tertinggi dalam kurun waktu empat tahun terakhir adalah sebesar 6.934 orang pada bulan april tahun 2016. Desa Wisata Sedit terletak di Desa Sedit dengan luas administratif mencapai 50,26 Hektar.

Seiring dengan perkembangan kegiatan wisata, pertumbuhan jumlah penduduk dan pembangunan sarana dan prasarana, pemanfaatan ruang di Desa wisata Sedit mengalami perubahan yang cukup signifikan. Hal ini dapat dilihat dari semakin banyaknya bermuncula pemanfaatan ruang yang tidak sesuai dengan peraturan pemanfaatan ruang yang telah ditetapkan, salah satunya semakin maraknya kegiatan alih fungsi lahan pertanian menjadi kawasan terbangun (Peraturan adat Desa Sedit).

Perkembangan Desa Wisata Sedit selama kurang lebih 4 tahun berpengaruh terhadap aspek fisik (perubahan penggunaan lahan). Baik pada lahan non terbangun menjadi terbangun maupun pada fungsi lahan. Perubahan lahan non terbangun menjadi terbangun berupa lahan tegalan yang menjadi perdagangan dan jasa. Sedangkan untuk perubahan penggunaan lahan terjadi pada penggunaan lahan tegalan dan sawah.

Setelah ditetapkan sebagai desa wisata pada Tahun 2014, berbagai aktivitas pariwisata semakin gencar dilakukan dan semakin banyak dikembangkan berbagai usaha dan fasilitas 
penunjang pariwisata hingga saat ini. Perkembangan aktivitas pariwisata yang terus terjadi menyebabkan terjadinya alih fungsi lahan.

Penelitian ini mengamati tentang perubahan penggunaan lahan yang terjadi karena dimanfaatkan untuk aktivitas pariwisata. Selain itu juga dicari aspek yang mendorong pemanfaatan lahan untuk aktivitas pariwisata tersebut. Dengan mengetahui fungsi lahan yang mengalami perubahan dan aspek yang dominan mendorong terjadinya perubahan penggunaan lahan, maka dapat menjadi saran dan masukan untuk merumuskan kebijakan terkait pengendalian pemanfaatan lahan berdasarkan konsep berkelanjutan.

\section{Metode Penelitian}

Penelitian dilakukan di Desa Sedit yang melingkupi batasan Desa Sedit, Kecamatan Bebalang, Kabupaten Bangli. Adapun pendekatan penelitian yang digunakan adalah pendekatan kualitatif dan pendekatan kuantitatif.

Membatasi permasalahan yang dibahas dalam penelitian ini, maka ruang lingkup dalam penelitian ini adalah alih fungsi lahan karena dimanfaatkan untuk sarana wisata.

\section{Jenis Data dan Teknik Pengumpulan Data}

Jenis data dalam penelitian ini berupa data kualitatif dan data kuantitatif. Teknik pengumpulan data yang digunakan dalam penelitian ini, meliputi observasi lapangan, telaah dokumen, dan wawancara. Observasi lapangan dan telaah dokumen, yaitu citra satelit tahun 2004 dan 2017 untuk mengetahui perubahan penggunaan lahan yang terjadi, sedangkan wawancara untuk mengetahui aspek dominan yang mendorong terjadinya penggunaan lahan untuk sarana wisata.

\section{Metode Analisis Data}

Adapun metode analisis yang digunakan dalam penelitian ini adalah dengan menggunakan analisis pemetaan dengan membandingkan peta dari tahun 2004-2017 dan metode analisis deskriptif. Peta penggunan lahan yang akan dianalisis adalah peta penggunaan lahan pada tahun 2004 dan peta penggunaan lahan eksisting tahun 2017. Adapun jenis data dan teknik pengambilan data yang dibutuhkan dapat dilihat melalui Tabel 1.

Tabel 1. Data yang Diperlukan

\begin{tabular}{lll}
\hline Jenis Data & Rincian Jenis Data & Sumber \\
\hline Kualitatif & - Jenis penggunaan lahan eksisting & - Observasi \\
& - Jenis penggunaan lahan pada & lapangan \\
& tahun 2004 & - Wawancara \\
& - Peruntukan lahan & - RTRW Kab. \\
& - Aspek ekonomi & Bangli \\
& - Infrastruktur & \\
& - Regulasi/kebijakan & \\
Kuantitatif & - kelembagaan & - Google Satelit \\
& & - Data Statistik \\
& & (Profil Desa Sedit) \\
\hline
\end{tabular}

Sumber: Analisis 2017 
Proses mencari dan menyusun data yang diperoleh dari hasil observasi, wawancara, studi pustaka, dan dokumentasi dijabarkan secara sistematis sehingga mudah dipahami dan selanjutnya dilakukan tahapan analisis data. Setelah pengumpulan data dilakukan analisis data. Pada penelitian ini menggunakan metode analisis deskriptif.

Untuk lebih jelasnya, metode penelitian pada penelitian ini dapat digambarkan melalui skema model penelitian sebagai berikut.

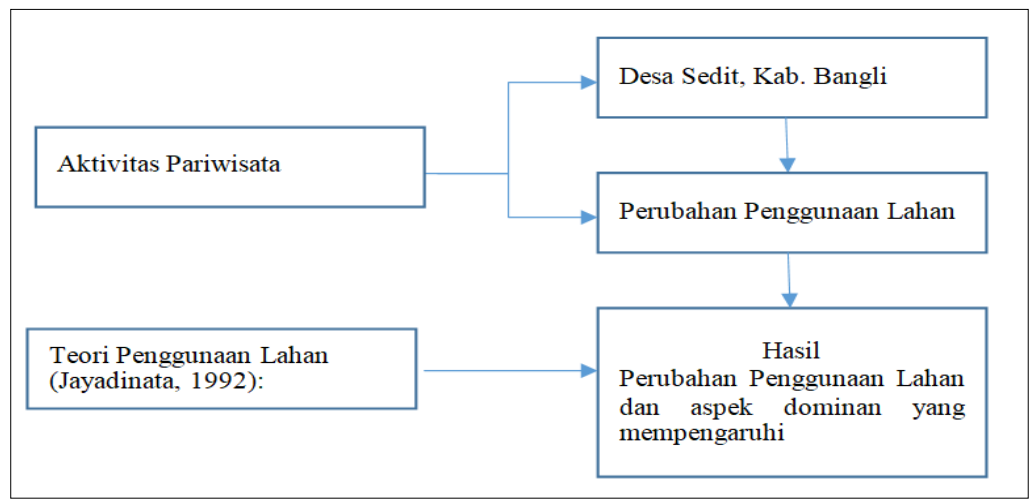

Gambar 1. Model Penelitian

Sumber: Analisis 2017

\section{Model Penelitian}

Model penelitian merupakan sintesis antara teori yang relevan dengan masalah penelitian. Masalah pokok dari penelitian ini adalah perubahan penggunaan lahan dan aspek dominan yang mendorong penggunaan lahan untuk aktivitas pariwisata. Adanya aktivitas pariwisata di Desa Sedit berdampak pada perubahan penggunaan lahan. Perubahan penggunaan lahan dapat dilihat dari adanya perbedaan pemanfaatan dari sebelumnya. Waktu pengamatan yang digunakan dalam penelitian ini adalah pada tahun 2004 dimana kawasan desa wisata secara satu kesatuan dilirik dan ingin dikembangkan berbagai aktivitas pariwisata. Kemunculan ide untuk pengembangan pariwisata di Desa Sedit didukung oleh berbagai program dari Pemerintah Kabupaten Bangli. Perkembangan terus terjadi hingga diresmikan secara hukum sebagai desa wisata. Setelah diresmikan secara hukum dengan Surat Keputusan Bupati, perkembangan aktivitas pariwisata menjadi semakin pesat hingga tahun 2017 sebagai tahun eksisting.

\section{Penelitian Sejenis}

Terdapat beberapa penelitian yang sudah dilakukan tentang dampak perkembangan pariwisata yang berkaitan dengan penggunaan lahan dan kondisi lingkungan baik berupa jurnal dan tesis oleh para peneliti. Penelusuran dilakukan untuk dapat membandingkan dan juga mengetahui posisi dari penelitian yang sudah dilakukan terhadap penelitian ini. Salah satunya adalah penelitian yang dilakukan oleh Istiqomah Tya Dewi Pamungkas mengangkat topik pengaruh keberadaan Desa Wisata Karangbanjar terhadap perubahan penggunaan lahan, ekonomi, dan sosial masyarakat. Tujuan penelitian ini adalah mengkaji Pengaruh Keberadaan Desa Wisata Karangbanjar Terhadap Perubahan Penggunaan Lahan, Ekonomi dan Sosial Masyarakat Karangbanjar. Penelitian ini dilakukan dengan tujuan untuk mengkaji 
pengaruh keberadaan Desa Wisata Karangbanjar terhadap perubahan penggunaan lahan, ekonomi dan sosial masyarakat.

\section{Teori Perubahan Penggunaan Lahan}

Perubahan penggunaan lahan sebagai dampak dari perkembangan desa wisata didorong oleh beberapa aspek. Menurut Lestari (2009) disebutkan tiga aspek penting yang menyebabkan terjadinya perubahan penggunaan lahan, meliputi aspek internal, aspek eksternal dan aspek kebijakan. Aspek internal dimana aspek ini lebih melihat sisi yang disebabkan oleh kondisi sosial-ekonomi rumah tangga pengguna lahan dan partisipasi masyarakat. Aspek eksternal merupakan aspek yang disebabkan oleh adanya dinamika pertumbuhan perkotaan/pedesaan oleh kemajuan teknologi, demografi, maupun ekonomi, dan kecenderungan. Aspek kebijakan merupakan aspek regulasi yang dikeluarkan oleh pemerintah pusat maupun daerah yang berkaitan dengan perubahan penggunaan lahan.

\section{Gambaran Umum Lokasi Penelitian}

\section{a. Letak Geografis}

Lokasi penelitian adalah Desa Sedit yang merupakan bagian dari wilayah administrasi Kecamatan Bebalang yang terletak di Kabupaten Bangli. Kondisi topografis Desa Sedit berupa hamparan lahan dataran mempunyai batas-batas wilayah yaitu di sebelah utara Desa Sedit adalah Desa Bebalang, di sebelah barat adalah Desa Tanggahan Tengah, di Sebelah selatan adalah Desa Sembung dan di sebelah timur adalah Desa Pulung. Namun, untuk lokasi penelitian dibatasi pada wilayah yang masuk dalam administrasi Desa Sedit, seperti pada Gambar 3.

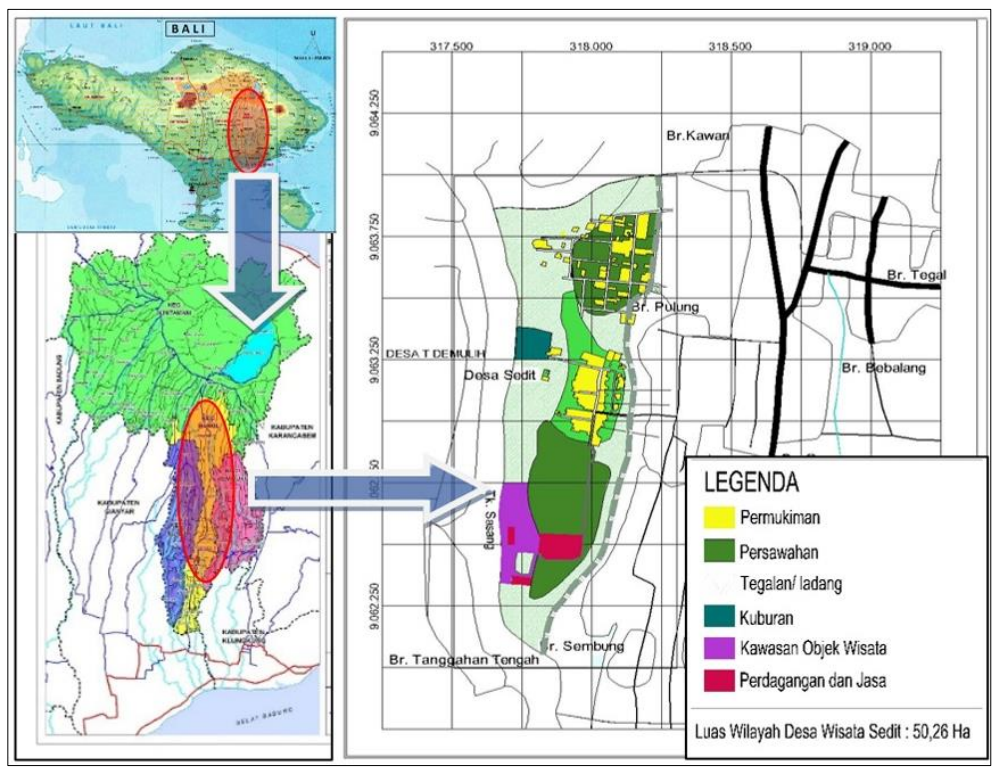

Gambar 3. Batas Lokasi Penelitian

Sumber: RTRW Kabupaten Bangli 


\section{b. Daya Tarik dan Sarana Wisata}

Salah satu hal yang dapat menjadi daya tarik wisata adalah keberadaan objek wisata di kawasan tersebut. Adapun objek wisata yang ada di Desa Wisata Sedit yaitu Pura Tirta Sudamala.

Pura Tirta Sudamala baru dikembangkan sebagai daya tarik wisata umum pada tahun 2012 diiringi dengan dibentuknya kelompok masyarakat sadar wisata. Seperti tempat-tempat melukat pada umumnya Pura Tirta Sudamala memberikan pemandangan alami yang menyatukan antara Pura, sumber mata air suci, hamparan persawahan dan keberadaan masyaratnya yang sampai saat ini masih menjujung nilai-nilai budaya dan spiritual

Sarana wisata yang ada di Desa Sedit, seperti warung, warung makan merupakan milik pribadi penduduk lokal Desa Sedit. Sebesar 64\% masyarakat mengembangkan usaha berupa tempat makan, sisanya berupa toko souvenir.

\section{Hasil Dan Pembahasan}

\section{a. Penggunaan Lahan Pada Tahun 2004}

Tahun 2004 terlihat jelas penggunaan lahan di Desa Sedit masih didominasi oleh penggunaan lahan dengan fungsi persawahan dan tegalan dapat dilihat pembagiannya dalam Tabel 2.

Tabel 2. Penggunaan Lahan di Desa Sedit Tahun 2004

\begin{tabular}{lll}
\hline Guna Lahan 2004 & Luas (Ha) & Prosentase (\%) \\
\hline Pemukiman & 9,2 & $18,3 \%$ \\
Persawahan & 25,71 & $51,2 \%$ \\
Tegalan/Ladang & 11,79 & $23,5 \%$ \\
Kuburan & 1 & $2 \%$ \\
Taman & - & - \\
Perdagangan dan Jasa & 0,5 & $1 \%$ \\
Kawasan Objek Wisata & 2,06 & $4,1 \%$ \\
Luas Total Desa Wisata Sedit & $\mathbf{5 0 , 2 6}$ & \\
\hline \multicolumn{2}{l}{ Sumber: Profil Kelurahan Bebalang Kec. Bangli Kab. Bangli Tahun 2004 }
\end{tabular}

Dari Tabel 2. dapat diketahui secara lebih jelas penggunaan lahan di Desa diketahui bahwa penggunaan lahan di Desa Sedit pada tahun 2004 di dominasi oleh penggunaan lahan persawahan, yaitu sebesar $24 \mathrm{Ha}$ atau 47,75\% dari luas Desa Sedit. Pada Tahun 2004 objek wisata yang telah berkembang, yaitu Tirta Sudamala dengan luasan 3,3 Ha atau sebesar 6,6\% dari total luasan Desa Sedit yang secara spasial dapat dilihat pada Gambar 4. 


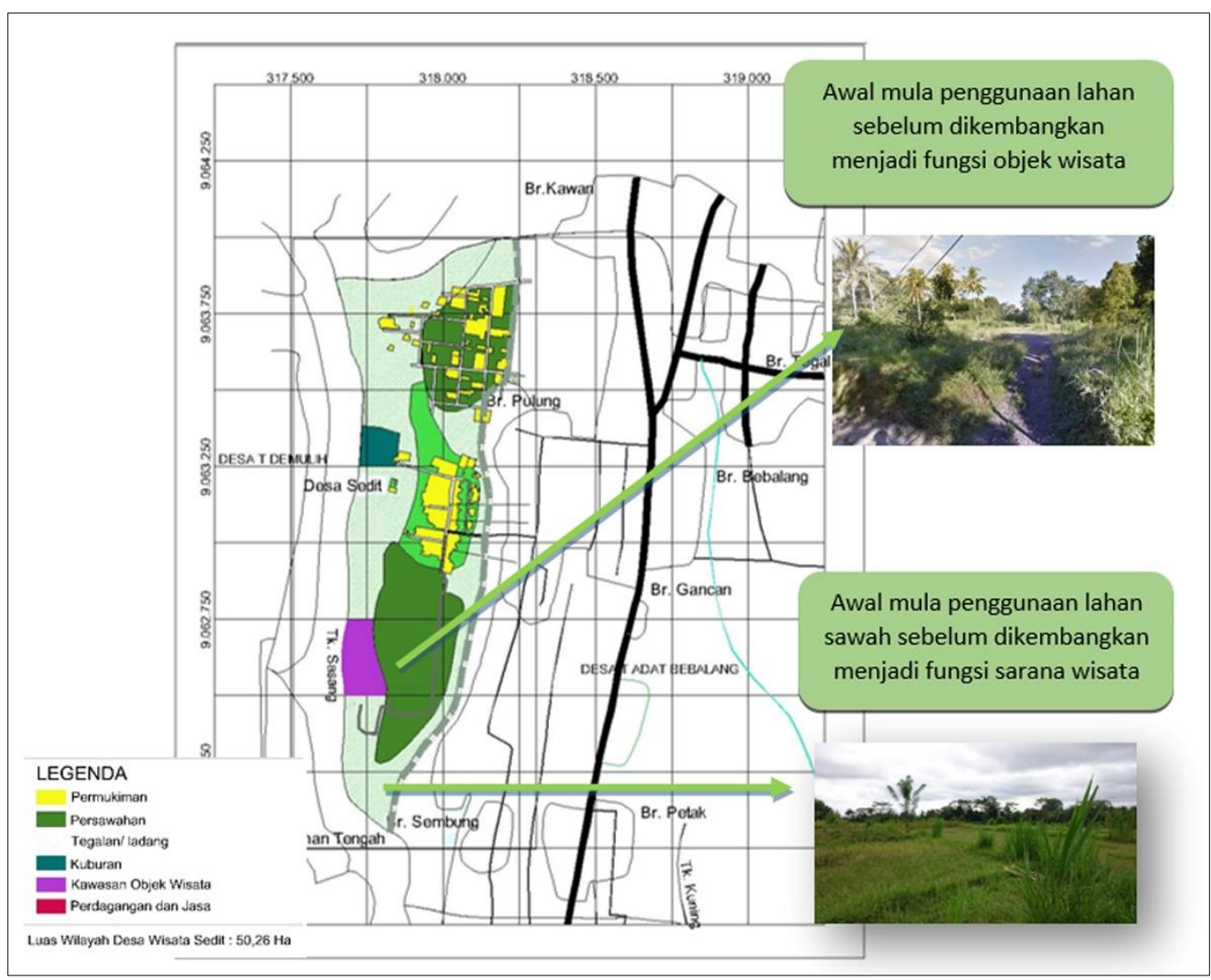

Gambar 4. Peta Penggunaan Lahan Tahun 2004 Sumber: RTRW Kabupaten Bangli

\section{b. Penggunaan Lahan Pada Tahun 2017}

Penggunaan lahan di Desa Sedit pada tahun 2017 masih didominasi oleh fungsi lahan persawahan. Namun, telah ditemukan adanya penambahan luasan lahan untuk sarana wisata. Berdasarkan hasil inventarisasi penggunaan lahan eksisting di Desa Sedit pada tahun eksisting dapat dilihat pada Tabel 3.

Tabel 3. Penggunaan Lahan di Desa Sedit Tahun 2017

\begin{tabular}{lcc}
\hline \multicolumn{1}{c}{ Guna Lahan 2017} & Luas & Keterangan \\
\hline Pemukiman & 9,55 & $\mathrm{Ha}$ \\
Persawahan & 23,87 & $\mathrm{Ha}$ \\
Tegalan/Ladang & 10,89 & $\mathrm{Ha}$ \\
Kuburan & 1 & $\mathrm{Ha}$ \\
Taman & - & - \\
Perdagangan dan Jasa & 1,65 & $\mathrm{Ha}$ \\
Kawasan Objek Wisata & 3,3 & $\mathrm{Ha}$ \\
Luas Total Desa Wisata Sedit & $\mathbf{5 0 , 2 6}$ & Ha
\end{tabular}

Sumber: Profil Kelurahan Bebalang Kec. Bangli Kab. Bangli Tahun 2017

Dari data pada Tabel 3, dapat diketahui bahwa dominan penggunaan lahan di Desa Sedit pada tahun 2017 adalah penggunaan lahan persawahan dengan luasan 23,87 Ha atau sebesar 47\% dari total luasan Desa Wisata Sedit.. Penggunaan lahan di Desa Sedit dapat dilihat melalui peta penggunaan lahan seperti pada Gambar 5. 


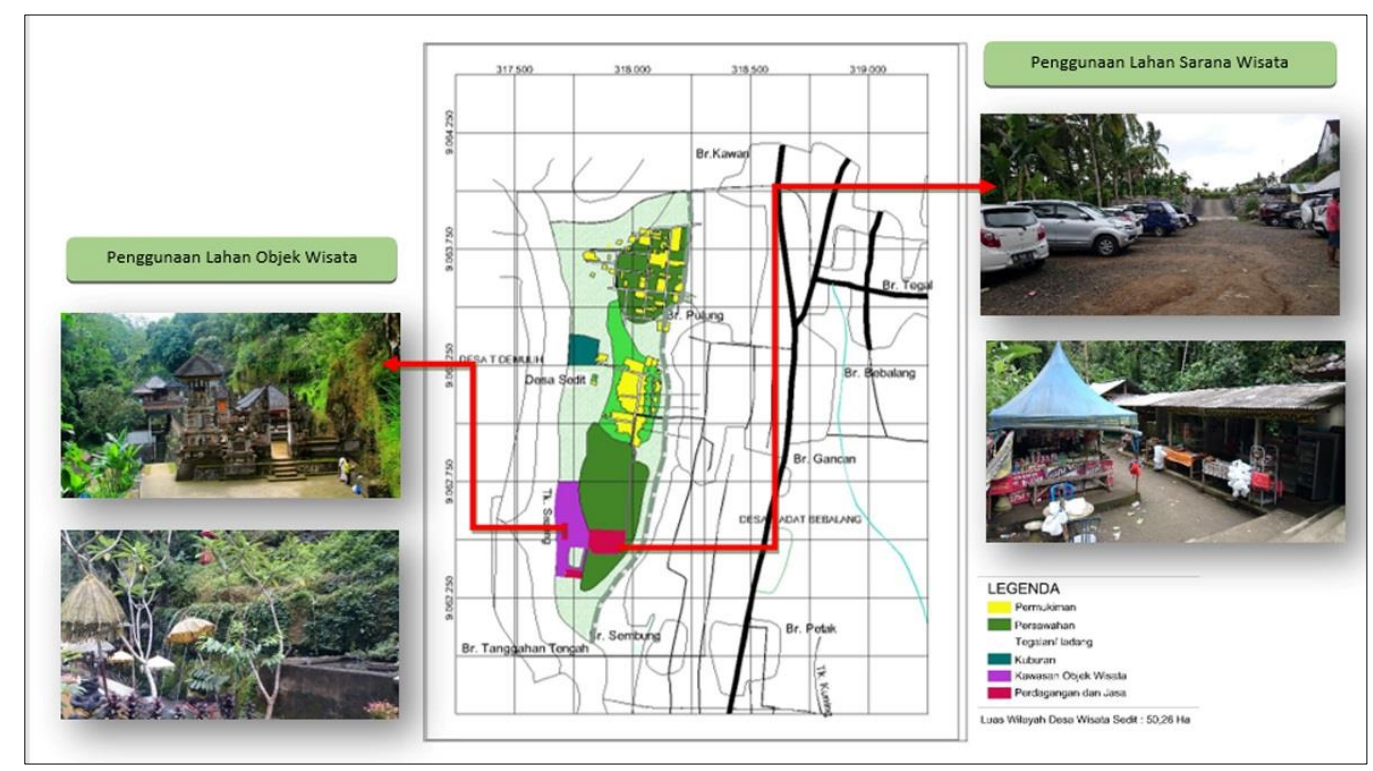

Gambar 5. Peta Penggunaan Lahan di Desa Sedit Tahun 2017 (Eksisting) Sumber: RTRW Kabupaten Bangli

\section{c. Alih Fungsi Lahan di Desa Sedit}

Jenis lahan yang mengalami perubahan adalah jenis lahan yang mengalami perubahan fungsi karena adanya suatu kondisi yang mempengaruhinya. Perubahan jenis lahan ini juga dapat dilihat sebagai perubahan fungsi lahan yang tidak sesuai dengan peruntukan awalnya. Dari hasil penelitian ini dapat diketahui bahwa, terdapat beberapa jenis lahan yang mengalami perubahan pemanfaatan. Perubahan dapat dilihat dari meningkat atau menurunnya luasan lahan yang ada. Beberapa jenis lahan yang mengalami peningkatan luasan, meliputi jenis lahan yang dimanfaatkan untuk objek wisata, permukiman, dan sarana pendukung kegiatan wisata. Jenis lahan yang mengalami penurunan luasan, meliputi penggunaan lahan persawahan dan lahan perkebunan. Dari beberapa jenis lahan yang mengalami penurunan luas, adapun yang paling banyak mengalami penurunan luas atau perubahan fungsi dan mengalami penyimpangan dari arahan tata ruang yang telah ditetapkan, yaitu jenis lahan persawahan yang mengalami perubahan fungsi sebesar $3,7 \%$.

Pada Rencana Tata Ruang Wilayah Kabupaten Bangli Tahun 2012 disebutkan, bahwa Desa Sedit merupakan salah satu kawasan strategis dengan fungsi sebagai kawasan budidaya. Fungsi pada kategori ini adalah wilayah yang ditetapkan dengan fungsi utama untuk dibudidayakan sehingga harus ada pengendalian penggunaan lahan agar fungsi utamanya tidak terganggu.

Pada perkembangannya, penggunaan lahan sebagai daya dukung lingkungan yang ada di Desa Sedit tidak dapat mempertahankan komposisi luasannya karena adanya aspek-aspek yang mendorong pemanfaatan lahan untuk pengembangan sarana wisata. Guna mengetahui perubahan penggunaan lahan yang terjadi, maka dilakukan analisis dengan membandingkan peta dari tahun 2004 sampai 2017 
Berdasarkan proses analisis seperti pada Gambar 6, memperlihatkan adanya perubahan pada beberapa penggunaan lahan karena dimanfaatkan untuk sarana wisata. Secara spasial, kawasan yang mengalami perubahan berdasarkan hasil analisis yang telah dilakukan dapat dipaparkan melalui Gambar 6.

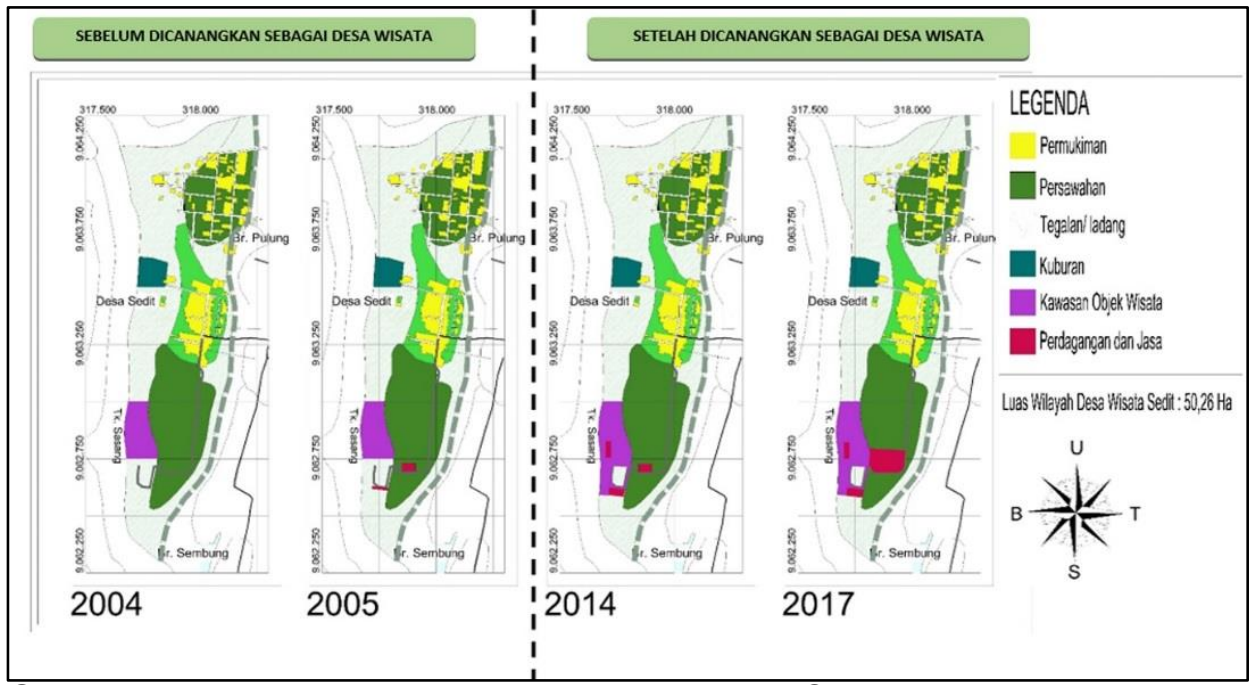

Gambar 6. Perubahan Penggunaan Lahan di Desa Sedit

Sumber: RTRW Kabupaten Bangli

Perubahan yang signifikan terjadi ditemukan di jalan menuju Objek Wisata yang pada awalnya penggunaan lahan dominan merupakan lahan persawahan. Menurut peraturan Adat Desa Sedit, daerah ini merupakan jalur hijau yang seharusnya tidak dimanfaatkan untuk kegiatan apapun.

Jika disandingkan, antara peta penggunaan lahan pada tahun 2004 dan 2017, maka dapat dilihat dengan jelas terjadi perbedaan penggunaan lahan yang dapat digambarkan melalui Tabel 4.

Tabel 4. Perbandingan Penggunaan Lahan pada Tahun 2004 dan Tahun 2017

\begin{tabular}{|c|c|c|c|c|c|}
\hline $\begin{array}{c}\text { Penggunaan } \\
\text { Lahan }\end{array}$ & $\begin{array}{c}\text { Luas } \\
\text { Lahan } \\
\text { Tahun } \\
\mathbf{2 0 0 4} \\
\text { (Ha) }\end{array}$ & $\begin{array}{c}\text { Luas } \\
\text { Lahan } \\
\text { Tahun } \\
2004 \\
\text { (Ha) }\end{array}$ & $\begin{array}{c}\text { Besar } \\
\text { Perubahan } \\
\text { (Ha) }\end{array}$ & $\begin{array}{c}\text { Prosentase } \\
\text { Perubahan } \\
(\%)\end{array}$ & Ket \\
\hline Pemukiman & 9,2 & 9,55 & 0,35 & $0,7 \%$ & Meningkat \\
\hline Persawahan & 25,71 & 23,87 & 1,84 & $3,7 \%$ & Menurun \\
\hline Tegalan/Ladang & 11,79 & 10,89 & 0,9 & $1,8 \%$ & Menurun \\
\hline Kuburan & 1 & 1 & - & - & $\begin{array}{l}\text { Tidak Ada } \\
\text { Perubahan }\end{array}$ \\
\hline $\begin{array}{l}\text { Perdagangan } \\
\text { dan Jasa }\end{array}$ & 0,5 & 1,65 & 1,15 & $2,3 \%$ & Meningkat \\
\hline $\begin{array}{l}\text { Kawasan Objek } \\
\text { Wisata }\end{array}$ & 2,06 & 3,3 & 1,24 & $2,5 \%$ & Meningkat \\
\hline Total & 50,26 & 50,26 & & & \\
\hline
\end{tabular}

Sumber: Profil Desa Sedit, 2004 dan 2017; Hasil Survey Lapangan, 2017 
Dari Tabel 4, dapat dianalisis bahwa terjadi perubahan penggunaan lahan karena dimanfaatkan untuk aktivitas pariwisata. dapat dilihat bahwa kawasan persawahan mengalami penurunan luasan, yaitu dari 25,71 Ha pada tahun 2004 menjadi 23,87 Ha pada tahun 2017. Hal ini menunjukkan bahwa adanya pemanfaatan lahan persawahan yang menyebabkan luasannya mengalami penurunan dan menyimpang dari arahan tata ruang yang telah ditetapkan. Tidak hanya persawahan yang mengalami penurunan luas, kasus yang sama juga terjadi pada penggunaan lahan tegalan/ladang. Lahan tegalan mengalami penurunan dari 11,79 Ha pada tahun 2004 menjadi 10,89 Ha pada tahun 2017. Kemudian, penggunaan lahan objek wisata menunjukan angka yang meningkat dari luasan 2,06 Ha pada tahun 2004 dan hingga sekarang pada tahun 2017 sudah berkembang menjadi 3,3 Ha. Hal ini membuktikan bahwa kegiatan wisata di Desa Wisata Sedit mengalami peningkatan.

Keberadaan objek wisata ini semakin didukung oleh adanya perdagangan dan jasa yang mendukung kegiatan wisata, yaitu yang pada tahun 2004 belum terdapat sarana pendukung namun kemudian berkembang hingga tahun 2017 luasan untuk sarana perdagangan dan jasa menjadi sebesar 1,65 Ha. Sarana pendukung kegiatan wisata ini berupa perdagangan dan jasa yang mendukung kegiatan wisata di Desa Wisata Sedit, seperti tempat makan dan toko.

Perbandingan luasan lahan pada tahun 2004 dan pada tahun 2017 yang dapat dilihat melalui Gambar 7 berikut.

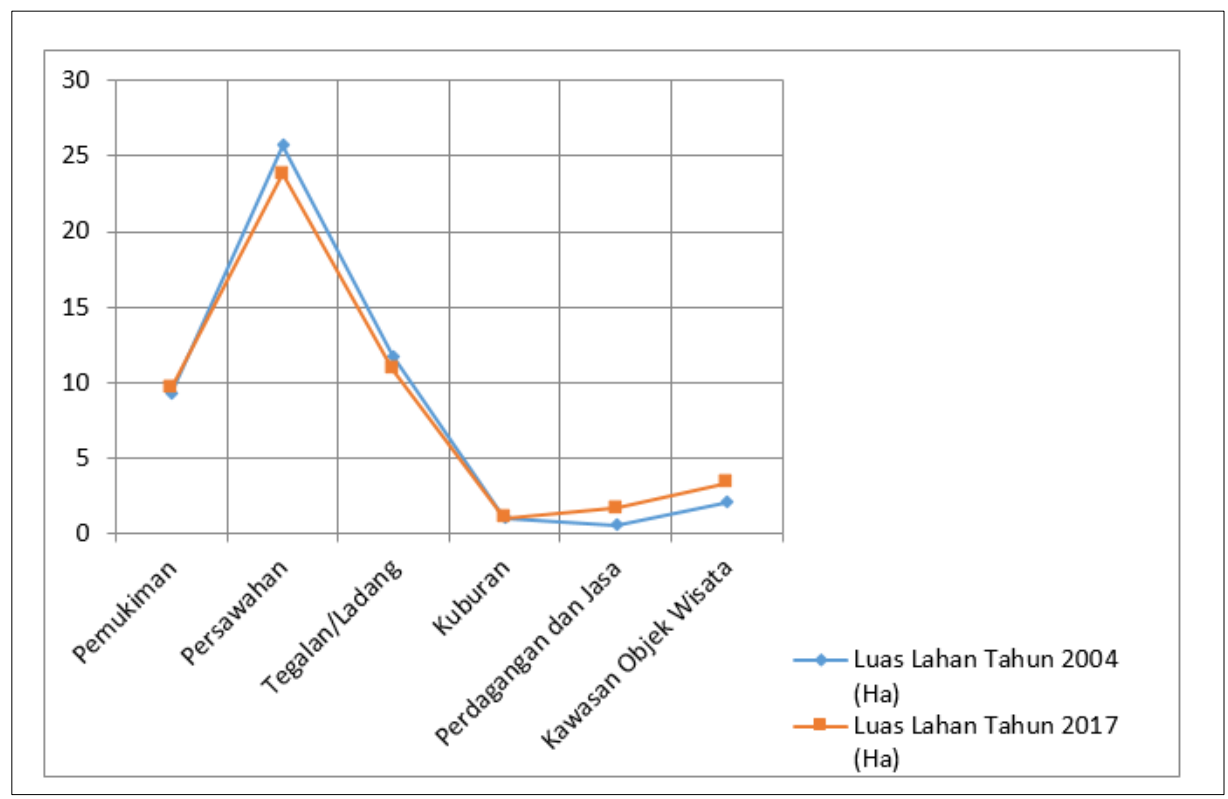

Gambar 7. Peta Perubahan Luasan Penggunaan Lahan Sumber: RTRW Kabupaten Bangli

\section{Aspek yang Mendorong Aktivitas Pariwisata}

Kemunculan berbagai sarana wisata di Desa Sedit tidak serta merta terjadi tanpa alasan. Terlebih lagi pengembangan sarana hampir seluruhnya dilakukan oleh penduduk lokal dan tidak ditemukan terdapat penduduk yang bukan merupakan penduduk asli Desa Sedit. Penduduk lokal memiliki alasan tersendiri yang membuat mereka memanfaatkan lahan miliknya, terutama pada fungsi kebun dan sawah untuk kemudian dikembangkan menjadi 
sarana wisata. Adapun aspek-aspek yang menjadi alasan terdorongnya penduduk untuk melakukan alih fungsi lahan tersebut. Aspek tersebut kemudian disebut sebagai variabel.

Terdapat beberapa aspek utama yang menyebabkan masyarakat setempat ikut berpartisipasi dalam kegiatan wisata di Desa Wisata Sedit, yaitu dengan mengembangkan usaha wisata yang merupakan sarana pendukung wisata dan mengakibatkan terjadinya perubahan lahan. Aspek-aspek yang dimaksud, meliputi aspek ekonomi, aspek partisipasi masyarakat, aspek perkembangan teknologi, aspek kecenderungan, dan aspek kebijakan. Masing-masing aspek tersebut dipilih oleh responden melalui pernyataan-pernyataan pada kuesioner yang kemudian dapat dirangkum pada Tabel 5 berikut:

Tabel 5. Variabel dan Indikator Pendorong Perubahan Penggunaan Lahan untuk Aktivitas Pariwisata

\begin{tabular}{lccccc}
\hline \multicolumn{1}{c}{ Pernyataan } & $\begin{array}{c}\text { Sangat } \\
\text { Setuju }\end{array}$ & Setuju & $\begin{array}{c}\text { Ragu- } \\
\text { Ragu }\end{array}$ & $\begin{array}{c}\text { Kurang } \\
\text { Setuju }\end{array}$ & $\begin{array}{c}\text { Tidak } \\
\text { Setuju }\end{array}$ \\
\cline { 2 - 6 } & (Orang) & (Orang) & (Orang) & (Orang) & (Orang) \\
\hline Ekonomi Rumah Tangga & 38 & 37 & 2 & 0 & 0 \\
Peluang kerja & 34 & 35 & 8 & 0 & 0 \\
Alih Profesi & 7 & 36 & 31 & 3 & 0 \\
Komunitas Pariwisata & 20 & 26 & 18 & 8 & 5 \\
Promosi Wisata & 3 & 9 & 19 & 26 & 20 \\
Kerjasama dengan Pihak Swasta & 4 & 24 & 20 & 18 & 11 \\
Minat Besar & 8 & 20 & 20 & 19 & 10 \\
Kemunculan Berbagai Usaha & 8 & 28 & 21 & 12 & 8 \\
Kebijakan Pengembangan & 2 & 10 & 15 & 33 & 17 \\
Kegiatan Pariwisata & & & & & \\
Ijin Desa Adat & 8 & 21 & 16 & 19 & 13 \\
Kebijakan Untuk Tidak Menjual & 11 & 25 & 24 & 11 & 6 \\
Lahan & & & & & \\
\hline
\end{tabular}

Sumber: Lestari (2009)

\section{a. Aspek Ekonomi}

Pengembangan aktivitas pariwisata didasarkan atas keinginan penduduk setempat untuk mencapai tingkat kesejahteraan yang lebih baik. Salah satunya dengan meningkatnya pendapatan. Indikator ini dapat dilihat dari meningkatnya pendapatan rata-rata per tahun pada beberapa sektor, yaitu sektor pertanian; perkebunan; peternakan; kerajinan; industri kecil, menengah, dan besar, serta jasa dan perdagangan.

Aspek ekonomi dalam penelitian ini ditinjau dari kehidupan ekonomi rumah tangga penduduk, peluang kerja, dan kecenderungan alih profesi penduduk. Berdasarkan penyebaran kuesioner sebagian besar masyarakat menyatakan sangat setuju bahwa perkembangan desa wisata membawa pengaruh yang besar bagi kehidupan ekonomi penduduk Desa Wisata Sedit sebanyak 49\%. Kemudian, masyarakat menyatakan sangat setuju bahwa perkembangan desa wisata memberikan peluang kerja yang lebih banyak sebanyak 44\%, karena dengan adanya kegiatan wisata maka semakin banyak lapangan kerja baru yang tercipta guna menunjang kegiatan wisata tersebut. Tidak hanya itu, didapatkan hasil juga yaitu sebesar $9 \%$ menyatakan sangat setuju bahwa perkembangan desa wisata di 
Desa Sedit mengakibatkan banyak warga beralih profesi karena beralasan bahwa profesi di bidang pariwisata memberikan pendapatan yang lebih baik dan tempat kerja sangat dekat dari rumah tinggal.

\section{b. Aspek Partisipasi Masyarakat}

Berdasarkan hasil kuesioner yang disebarkan, didapatkan bahwa sebagian masyarakat mengatakan setuju bahwa keberadaan komunitas pariwisata di Desa Sedit dapat menyebabkan terjadinya perubahan lahan karena mendorong penduduk setempat untuk ikut berpartisipasi mengembangkan berbagai kegiatan wisata di Desa Sedit yaitu sebanyak 35\% atau 26 orang. Selain itu, kelompok pariwisata di Desa Sedit juga secara langsung berkecimpung dalam pengembangan objek wisata yang ada di Desa Sedit yang mana pengembangannya menimbulkan perubahan lahan juga.

\section{c. Aspek Perkembangan Teknologi}

Perkembangan teknologi merupakan salah satu aspek yang mendorong perkembangan lahan terjadi di Desa Sedit sebagai desa wisata. Kemajuan teknologi dapat dilihat dari aksesibilitas dan ketersediaan sarana dan prasarana pendukung. Berdasarkan penyebaran hasil kuesioner menunjukkan bahwa, sebagian masyarakat menyatakan sangat setuju bahwa aksesibilitas Desa Wisata Sedit merupakan salah satu faktor yang mendorong perkembangan desa wisata yaitu sebanyak 4\%. Berdasarkan hasil pengamatan di lapangan dan tinjauan kebijakan, disebutkan bahwa Desa Sedit dilalui oleh jaringan jalan dengan kualitas yang sangat baik dan memiliki mobilitas yang tinggi. Selain itu, berbagai moda transportasi telah mengikuti kemajuan teknologi sehingga Desa Sedit dapat dicapai dengan mudah menggunakan jenis moda transportasi apapun. Sementara, sebagian masyarakat menyatakan bahwa aspek lain dalam kemajuan teknologi yang mendorong perkembangan desa wisata di Desa Wisata Sedit adalah ketersediaan sarana dan prasarana pendukung pariwisata sebanyak $4 \%$.

\section{d. Aspek Kecenderungan}

Aspek kecenderungan merupakan salah satu aspek yang mendorong perkembangan lahan terjadi di Desa Sedit sebagai desa wisata. Kecenderungan/tren dapat dilihat dari besarnya minat penduduk dalam ikut serta mengembangkan desa wisata dan kemunculan berbagai usaha pariwisata yang kemudian cenderung diikuti oleh penduduk lainnya. Berdasarkan hasil kuesioner yang disebarkan, diketahui bahwa sebagian masyarakat menyatakan sangat setuju bahwa penduduk lokal Desa Sedit memiliki minat yang besar dalam ikut serta berpartisipasi dalam perkembangan desa wisata sebanyak $10 \%$ atau 8 orang. Minat yang besar dari penduduk lokal ditunjukan dari adanya peran masyarakat dalam berbagai bidang, seperti keikutsertaan dalam kelembagaan/organisasi pariwisata yang ada di Desa Sedit dan keikutsertaan dalam menyebarkan informasi pariwisata. Minat penduduk juga ditunjukan dengan adanya usaha yang mendukung kegiatan pariwisata yang dikembangkan oleh penduduk setempat. 


\section{e. Aspek Kebijakan}

Adanya penetapan ini mendorong pemerintah dan masyarakat setempat untuk berperan aktif dalam mengembangkan pariwisata di Desa Sedit. Hal ini dilakukan untuk memajukan nama Desa Sedit sehingga menjadi lebih dikenal sebagai desa wisata. Pengembangan pariwisata dilakukan secara fisik dan juga non fisik.

Berdasarkan hasil wawancara dengan Bendesa Adat di Desa Bebalang menyebutkan bahwa, Desa Sedit memiliki kebijakan lokal bahwa masyarakat lokal tidak diperbolehkan menjual lahan miliknya kepada orang yang bukan merupakan penduduk asli Desa Sedit. Hal ini bertujuan untuk meminimalisir penduduk pendatang yang tidak terdaftar dalam Banjar Adat Sedit, mengingat ada aturan tidak boleh melakukan alih fungsi lahan.

\section{Aspek Dominan yang Mendorong Penggunaan Lahan untuk Aktivitas Pariwisata}

Berdasarkan hasil wawancara yang dilakukan dengan enam responden yang telah ditentukan terlebih dahulu. Dari hasil wawancara dilihat berapa banyak responden menjelaskan terkait aspek-aspek yang mendorong penggunaan lahan untuk aktivitas pariwisata berdasarkan hasil rekaman.

Hasil dari wawancara menjelaskan aspek ekonomi merupakan aspek dominan yang mendorong pemanfaatan lahan untuk pengembangan sarana wisata. Masyarakat sebagai responden dalam penelitian ini beranggapan kebutuhan hidup semakin meningkat sehingga masyarakat harus pintar melihat kondisi yang ada bahwa di Desa Sedit sedang berkembang aktivitas pariwisata. Mengingat lahan pertanian tidak produktif lagi, maka masyarakat melakukan terobosan di bidang yang berbeda untuk memanfaatkan lahan.

\section{Kesimpulan dan Saran}

Berdasarkan hasil pengamatan dan temuan perubahan penggunaan lahan yang terjadi di Desa Sedit, ada beberapa saran /rekomendasi yang perlu ditindaklanjuti dalam upaya pengendalian pemanfaatan lahan, sehingga dapat mengurangi terjadinya penyimpangan pemanfaatan karena tidak sesuai dengan peruntukannya. Saran tersebut yaitu meningkatkan dan mengoptimalkan pengawasan dan penertiban bangunan-bangunan yang dibangun pada lahan yang ada di Desa Sedit. menerapkan system insentif dan disinsentif pemanfaatan lahan, serta penelitian ini diharapkan dapat memperkaya referensi pustaka bidang pengembangan wilayah, khususnya wilayah pedesaan mengenai rencana pemanfaatan lahan dan pengendalian yang harus dilakukan, merancang produk tata ruang terkait pengendalian pemanfaatan lahan lebih disosialisasikan secara kontinyu kepada seluruh lapisan masyarakat di Desa Sedit, dan hasil penelitian ini diharapkan dapat menjadi referensi yang berguna untuk memahami dan mengembangkan lebih lanjut penelitian semacam ini atau kajian yang lebih mendalam.

Konsep pengendalian perubahan penggunaan lahan pertanian adalah dengan melibatkan peran serta aktif segenap pemangku kepentingan (stakeholders) sebagai entry point perencanaan, pelaksanaan, pengawasan, dan penilaian perundang-undangan dan peraturan yang ada. Partisipasi masyarakat tidak akan terwujud bila tidak diiringi dengan pendekatan 
dalam bentuk sosialisasi dan advokasi. Hal demikian mengingat masyarakat sendiri memiliki tipologi kemajemukan yang antara lain dicirikan oleh perbedaan sosial dengan ikatan kaidah, institusi, dan perilaku.

Mengingat lebih gencarnya proses perubahan penggunaan lahan di Desa Sedit maka prioritas konsep pengendaliannya adalah berlandaskan falsafah manusia mengikuti lahannya. Salah satu maknanya, apabila penempatan dan pengelolaan lahan diatur sedemikian rupa secara partisipatif, maka masyarakat akan mengikuti aturan-aturan tersebut. Jadi, fokus utamanya adalah penegakan (enforcement) perundang-undangan dan peraturan penggunaan lahan secara konsekuen.

\section{Daftar Pustaka}

Anonim. (2017). Data Statistik Kabupaten Bangli. Bali: Badan Pusat Statistik

Istiqomah, T. D. P. (2015). Pengaruh Keberadaan Desa Wisata Karangbanjar Terhadap Perubahan Penggunaan Lahan, Ekonomi, Dan Sosial Masyarakat. Jurnal Fakultas Teknik, Universitas Diponegoro.

Jayadinata, J. T. (1999).Tata Guna Tanah dalam Perencanaan Pedesaan, Perkotaan dan Wilayah. Bandung: ITB.

Kementerian Agraria dan Tata Ruang. 2007. Undang-Undang Penataan Ruang Nomor 26. Jakarta: Direktorat Jenderal Penataan Ruang.

Lestari. (2009). “Aspek-Aspek Terjadinya Alih Fungsi Lahan” (tesis). Sumatera Utara. Universitas Sumatera Utara

Profil. Kelurahan Bebalang Tahun (2004-2016).

Pemerintah Kabupaten Bangli. (2014). Surat Keputusan Bupati Nomor 16 Tahun 2014 tentang Penetapan Desa Wisata di Sedit. Bangli: Pemerintah Kabupaten Bangli.

Pemerintah Propinsi Bali. (2009). Peraturan Daerah tentang Rencana Tata Ruang Wilayah Propinsi Bali. Denpasar: Pemerintah Propinsi Bali.

Rencana Tata Ruang Wilayah Kabupaten Bangli Tahun 2002 - 2012

Samadhi, T.N. (2004). Perilakudan Pola Ruang. Malang : Lembaga Penelitian dan Pengabdian Masyarakat Jurusan Teknik Planologi, Institut Teknologi Nasional.

Sujarto, D. (1986). Perencanaan Kota Baru. Bandung, Penerbit ITB.

Warpani, S. P. \& Indira P. W. (2007). Pariwisata Dalam Tata Ruang Wilayah. Bandung, ITB.

\section{Ucapan Terimakasih}

Pada kesempatan ini perkenankanlah penulis mengucapkan terimakasih yang sebesarbesarnya Kepada:

1. Bapak Dr. Ngakan Ketut Acwin Dwijendra, ST., MA. selaku pembimbing I

2. Bapak Dr. Ir. I Made Adhika, MSP. selaku pembimbing II

3. Ibu Dr. Ir. Ni Ketut Siwalatri, MT. selaku Koordinator Program Studi Magister Arsitektur beserta jajarannya sebagai pelaksana teknis kegiatan Program Studi Magister Arsitektur

4. Klian Desa Sedit

5. Mayarakat Desa Sedit 